\title{
TINJAUAN LITERATUR PENGEMBANGAN INSTRUMEN PENILAIAN KEMAMPUAN BERPIKIR TINGKAT TINGGI (HOTS) FISIKA DI SMA
}

\author{
Eka Desiriah"), Woro Setyarsih"1, \\ 1)Jurusan Fisika, Fakultas Matematika dan Ilmu Pengetahuan Alam, Universitas Negeri Surabaya, Surabaya, \\ Jawa Timur, Indonesia \\ Corresponding author : Eka Desiriah \\ E-mail : eka.17030184059@mhs.unesa.ac.id
}

Diterima 03 April 2021, Direvisi 21 April 2021, Disetujui 22 April 2021

\begin{abstract}
ABSTRAK
Kemampuan Berpikir Tingkat Tinggi (HOTS) merupakan kemampuan peserta didik dalam menginterpretasikan pengetahuannya dalam menyelesaikan suatu permasalahan melalui proses analisis, evaluasi hingga menciptakan ide dari permasalahan yang di sajikan. Kajian ini memiliki tujuan untuk mengidentifikasi pengembangan instrumen penilaian kemampuan berpikir tingkat tinggi (HOTS) Fisika di SMA. Penelitian review ini menggunakan metode bibliometrik dan pendekatan kualitatif dalam mengkaji jurnal pada tahun 2016-2020. Berdasarkan hasil analisis menunjukkan bahwa pengembangan instrumen HOTS dilakukan berdasarkan pada tuntutan dari abad ke-21 dan hasil survey yang dilakukan oleh PISA dan TIMMS. Salah satu bentuk penilaian yang dikembangkan adalah soal tes dengan tipe instrumen pilihan ganda, pilihan ganda beralasan dan uraian. Soal tes yang dikembangkan memperhatikan ciri-ciri HOTS seperti memperhatikan indikator-indikator HOTS, KKO, permasalahan fisika dan stimulus, serta taksonomi bloom. Materi yang banyak dikembangkan yaitu suhu dan kalor, getaran harmonis, fluida statis dan dinamis. Metode yang sering digunakan dalam penelitian pengembangan ini adalah metode R\&D dari Brog and Gall, metode 4D, metode deskriptif kualitatif, dan metode ADDIE. Instrumen HOTS dilakukan proses uji dan analisis kelayakan diantaranya yaitu uji kevalidan dari validator, uji validitas, uji reliabilitas, uji tingkat kesukaran, uji daya beda, analisis model Rasch, analisis dengan formula Alpha Cronbach dan uji pengecoh soal.
\end{abstract}

Kata kunci: pengembangan instrument penilaian; kemampuan berpikir tingkat tinggi; Fisika; SMA.

\begin{abstract}
High Order Thinking Skill (HOTS) is ability of students to interpret their knowledge in solving problems through process of analysis, evaluation to create ideas from the problems presented. This study aims to identify the development of HOTS assessment instruments for high school physics. This review research uses bibliometric method and qualitative approach to reviewing journals in 2016-2020. Based on the results of the analysis, it shows that the development HOTS instrument based on the demands of the 21st century and the survey results by PISA and TIMMS. The type of assessment instrument that developed is test item with multiple choice, reasoning multiple choice, and essay. To developed test questions must regard to HOTS characteristics such as HOTS indicators, KKO, physics problems, stimulation, and bloom taxonomy. The most materials that developed are temperature and heat, harmonic vibration, static and dynamic fluids. The methods that often used is $R$ \& $D$ method from Brog and Gall, 4D stage, qualitative descriptive and ADDIE. HOTS instrument will be test process and feasibility analysis including expert validation, validity,reliability, difficulty level, item discrimination analysis, Rasch model analysis, Cronbach Alpha formula analysis and item distractor analysis.
\end{abstract}

Keywords: development assessment instrument; high order thinking skill; physics; senior high school.

\section{PENDAHULUAN}

Saat ini dunia sudah berada dalam era revolusi industri 4.0. Dalam era revolusi industri 4.0 peserta didik diharapkan mampu menguasai keterampilan abad ke-21 yang terdiri atas tiga kemampuan utama yaitu kemampuan berpikir, kemampuan bertindak, dan kemampuan hidup (Marwan et al., 2020). Semakin berkembangannya era revolusi maka persaingan kualitas sumber daya manusia
(SDM) semakin ketat. Sehingga dibutuhkan peningkatan mutu pendidikan(Akhsan et al., 2019). Menurut UU No. 20 Tahun 2003 Pendidikan adalah suatu usaha peserta didik untuk membangun keadaan belajar dan proses pembelajaran yang aktif sehingga dapat mengembangkan potensi dirinya. Hasil survey yang dilakukan PISA pada tahun 2018 sendiri menunjukkan bahwa capaian mutu pendidikan Indonesia mengalami penurunan dibandingkan 
survey pada tahun 2015 (Sains, 2019). Kemampuan peserta didik Indonesia dalam sains memiliki skor rata-rata yang masih dibawah negara-negara OECD (Organisation for Economic Cooperation and Development). Sehingga dengan hasil tersebut diperlukan peningkatan capaian mutu pendidikan di Indonesia (Kementrian Pendidikan Dan Kebudayaan, 2019a).

Berdasarkan nilai rata-rata nasional menunjukkan bahwa nilai rata-rata nasional fisika tidak mencapai nilai 50 dari rentang 100. Hal ini mengidentifikasikan bahwa kemampuan kognitif fisika yang dimiliki peserta didik masih rendah (Kurniawan et al., 2020). Menurut Atasoy (Erfianti et al., 2019), dalam memperlajari ilmu Fisika dibutuhkan kemampuan memahami konsep dan memahami cara pengaplikasian dalam pemecahan masalah. Untuk mencapai hal tersebut dibutuhkan perubahan konsep pengetahuan awal yang sesuai dengan keadaan sesungguhnya. Agar dapat mengubah konsep pengetahuan awal menjadi pengetahuan jangka panjang dibutuhkan suatu metode yang disebut kemampuan berpikir tingkat tinggi (Supahar\&Saputro, 2018).

Kemampuan Berpikir Tingkat Tinggi (HOTS) yaitu suatu keterampilan peserta didik dalam memahami pengetahuan yang tidak hanya mengingat saja tetapi juga mengajarkan dalam menghubungkan informasi-informasi yang dimiliki dalam tingat berpikir yang lebih tinggi hingga mampu menganalisis dan menciptakan suatu ide (Widyastuti, 2017). Hal ini mengidentifikasikan bahwa dengan kemampuan berpikir tingkat tinggi diharapkan mampu dalam memperoleh solusi dari suatu permasalahan (Ayumniyya \& Setyarsih, 2021). Karthworl dan Anderson menyatakan bahwa dalam Taksonomi Bloom yang telah direvisi terdapat tiga level kognitif yang mengukur HOTS yaitu C4 (kemampuan menganalisis), C5 (kemampuan mengevaluasi), dan C6 (kemampuan mencipta) (Liana et al., 2018). Sedangkan Schraw menyatakan bahwa terdapat empat komponen HOTS seperti pada Gambar 1. sebagai berikut:

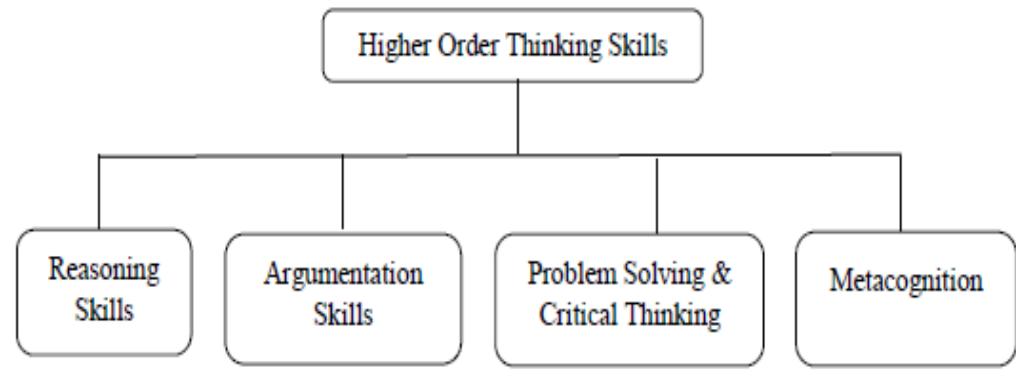

Gambar 1. Komponen HOTS (sumber : Serevina et al., 2018)

Popham menyatakan bahwa kesuksesan pendidikan berjalan baik apabila didukung penilaian yang baik pula dan memberikan dampak dalam proses pembelajaran selanjutnya. Ketepatan dalam penentuan metode penilaian akan berdampak pada objektivitas dan validitas hasil penilaian sedangkan kesalahan dalam pemilihan metode penilaian dapat memberikan informasi yang tidak benar terhadap kualitas pendidikan (Setiadi, 2016). Menurut Permendikbud No. 69 Tahun 2013 salah satu dari empat kompetensi yang harus dicapai yaitu kompetensi inti pengetahuan. Allen \& Friedman (Setiadi, 2016) menyatakan bahwa kesulitan dari pembelajaran adalah mengintegrasikan berbagai domain yaitu kognitif, perilaku dan emosi.

Penilaian HOTS merupakan penilaian yang menyajikan soal tes pada level kognitif tingkat tinggi kepada peserta didik sehingga dapat meningkatkan kemampuan berpikir kritis dan berpikir kreatif (Hidayah et al., 2018). Penilaian HOTS memiliki tiga prinsip utama yaitu (1) pemberian stimulus baik dalam bentuk teks maupun bentuk lainnya, (2) pemberian permasalahan baru yang belum diberikan di kelas, (3) pemberian soal dengan tipe kesukaran yang berbeda dan level kognitif yang berbeda-beda. Dalam merumuskan indikator soal HOTS biasanya menggunakan kata kerja operasional (KKO) berdasarkan taksonomi bloom untuk mengetahui dimensi pengetahuan yang diukur oleh soal tersebut (Kementrian Pendidikan Dan Kebudayaan, 2019b).

Barnett dan Francis menyatakan bahwa pemberian soal-soal HOTS dapat membuat peserta didik memahami materi yang disampaikan secara lebih mendalam (Kusuma et al., 2017). Dalam konteks asesmen Soal-soal HOTS dapat digunakan untuk mengukur (1) keterampilan pemahaman antar konsep, (2) pengintegrasian dan pemrosesan informasi, (3) pencarian keterkaitan informasi yang diperoleh, (4) proses penggunaan informasi untuk menyelesaikan masalah (problem solving) dan (5) kemampuan dalam menemukan ide baru dari informasi tersebut (Kementrian Pendidikan Dan Kebudayaan, 2019b). Dengan demikian 
penggunaan instrumen penilaian HOTS dapat digunakan sebagai sarana meningkatkan kemampuan peserta didik memahami materi dan dapat digunakan seorang guru dalam mengevaluasi pembelajarannya (Kusuma et al., 2017).

Adapun tujuan dari kajian ini untuk mengetahui alasan pengembangan instrument, jenis penilaian dan bentuk instrumen yang digunakan, indikator pembuatan soal, materi fisika yang diteliti, metode penelitian yang diterapkam dan bagaimana menentukan hasil yang dapat dipertanggungjawabkan dari pengembangan instrumen penilaian kemampuan berpikir tingkat tinggi (HOTS) Fisika di SMA. Hasil dari kajian ini dapat memberikan pengetahuan mengenai poin-poin penting terkait dengan pengembangan instrumen penilian kemampuan berpikir tingkat tinggi (HOTS) Fisika di SMA.

\section{METODE PENELITIAN}

Artikel penelitian ini merupakan artikel kajian literatur yang dilakukan pada 23 jurnal tahun 2016-2020. Metode yang dipakai yaitu metode bibliometrik dan pendekatan kualitatif. Blibliometrik adalah menganalisis literatur atau buku dengan menggunakan pendekatan matematis dan statika (Sidiq, 2019). Pendekatan kualitatif yang dimaksud yaitu dengan menghasilkan data deskriptif berupa kata-kata tertulis berdasarkan hasil yang diperoleh.

\section{Prosedur Penjaringan Data}

Perolehan data primer penelitian ini dilakukan pada bulan Oktober tahun 2020 melalui penjaringan meta data menggunakan software aplikasi publish or perish pada database publikasi Google Scholar untuk batasan tahun 2016-2020 dengan kata kunci "Pengembangan instrumen penilaian HOTS Fisika di SMA". Hasil penjaringan pertama diperoleh 891 data. Data tersebut diextract ke Microsoft Excel dan dilakukan pemilahan artikel sesuai dengan topik dan tujuan penelitian. Hasil pemilahan data dipilah kembali dengan menggunakan kriteria yaitu (1) berupa artikel, (2) bukan proceeding, (3) dipublikasikan pada jurnal yang memiliki ISSN, dan (4) tersedia dalam bentuk PDF. Pada seleksi tahap kedua ini diperoleh 23 data. 23 artikel yang didapatkan dimasukkan ke dalam aplikasi mendeley untuk dilakukan pengecekan sekaligus dilengkapi atribut datanya seperti nama penulis, nomor, volume, tahun dan abstrak jurnal untuk kemudian di extract menjadi file bentuk ris. Langkah-langkah proses penjaringan data dalam penelitian ini sebagai berikut.

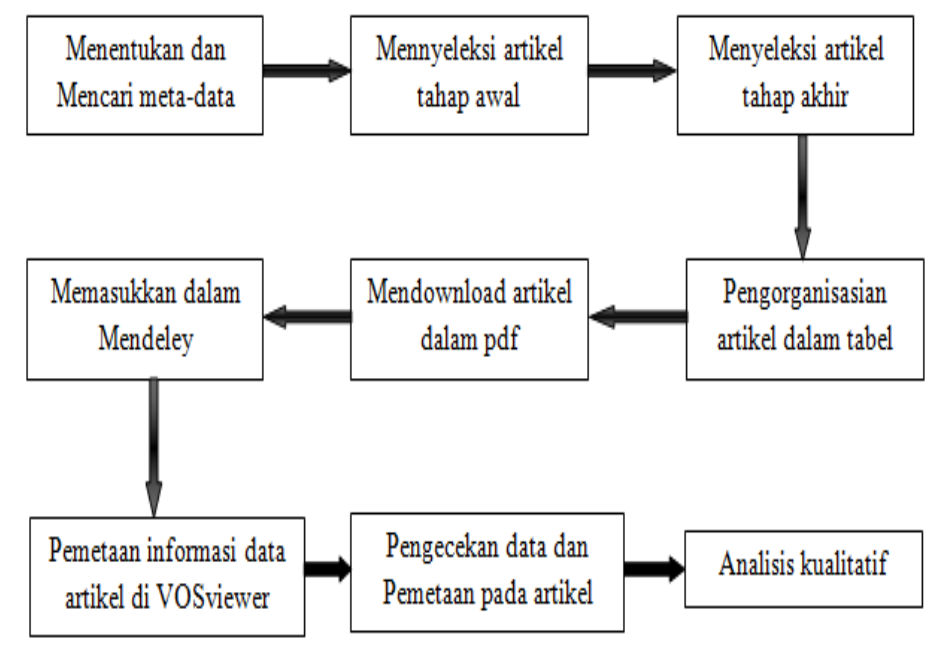

Gambar 2. Alur perolehan data dan proses analisis (Serevina et al., 2019)

\section{Pemetaan Data Analisis}

Metode bibliometrik merupakan metode untuk mengaji suatu literatur dengan menggunakan pendekatan statistika. Untuk memperoleh data statistika tersebut maka data dalam bentuk ris tersebut dilakukan analisis mennggunakan aplikasi vosviewer dengan keterakitan pada judul dan abstrak artikel. Hasil dari keterkaitan judul dan abstrak dilakukan penyeleksian kata-kata yang mendukung penelitian seperti berkaitan dengan alasan pengembangan, bentuk penilaian dalam pengembangan, karakteristik hots, metode penelitian, dan bentuk analisis yang dipakai.

\section{Analisis Data}

Hasil pemetaan Vosviewer membentuk jejaring berhubungan antar atribut data dan menjadi beberapa kluster. Kata-kata pada kluster-kluster tersebut diidentifikasi dan dipilih sesuai dengan tujuan penelitian. Visualisasi hasil pemetaan VOSviewer ditampilkan dan 
direkam sebagai acuan menganalisis dan mereview semua artikel. Setelah itu dilakukan paparan deskriptif mengenai kata-kata tersebut secara berurutan sesuai dengan tujuan penelitian.

\section{HASIL DAN PEMBAHASAN}

Keterkaitan antar artikel dilihat dari judul dan abstraknya dapat memberikan informasi yang lebih luas. Hal ini dapat dilihat dari segi analisisnya yang memiliki cakupan referensi yang luas sehingga pembagian klusternya bisa menjadi semakin efektif. Pada keterkaitan judul dan abstrak VOSviewer menampilkan kata-kata yang muncul membentuk jaringan yang berkaitan dan menjadi beberapa kluster. Setiap artikel yang memiliki kesamaan kata dengan artikel lain akan masuk dalam kluster yang sama seperti yang terlihat pada Gambar 3 .

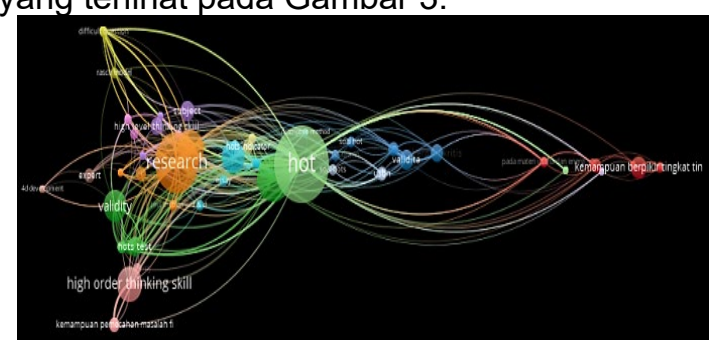

Gambar 3. Tampilan VOSviewer pada keterkaitan kata

Dari hasil analisis teridentifikasi pada 759 item/kata ditemukan kemudian dilakukan pemilahan kata kunci yang menggambarkan penelitian maka terbagi dalam 18 kluster. Berdasarkan pemetaan pada Gambar 3, tersusun kata kunci pada masing-masing kluster seperti pada Tabel 1.

Tabel 1. Kluster dalam Penelitian

Pengembangan Instrumen HOTS.

\begin{tabular}{cl}
\hline No. & \multicolumn{1}{c}{ Kata-kata pada Kluster } \\
\hline 1 & $\begin{array}{l}\text { bentuk soal, elastisitas dan hukum hooke, paper } \\
\text { test, hots instrument, kko, kontekstual dan } \\
\text { menggunakan stimulus, penelitian r \& d }\end{array}$ \\
\hline 2 & $\begin{array}{l}\text { brog, gall development model, high reliability, } \\
\text { legibility, gerak lurus berubah beraturan, } \\
\text { moderate level, multiple choice question, } \\
\text { getaran harmonis, suhu dan kalor, physics } \\
\text { expert, realibility, reason, spss application, test } \\
\text { characteristic, validity }\end{array}$ \\
\hline 3 & $\begin{array}{l}\text { daya beda soal, koefisien reliabilitas, stimulus, } \\
\text { adaptasi model Brog \& Gall }\end{array}$ \\
\hline 4 & $\begin{array}{l}\text { Analisis reliabelitas dan validitas, empat } \\
\text { langkah, cronback alpha, penilaian validator, } \\
\text { research dan development, tiaragajan. }\end{array}$ \\
\hline 5 & $\begin{array}{l}\text { 4d stage, aiken, borg \& gall, expert validation, } \\
\text { hots assessment instrument, hots indicator, pisa } \\
\text { survey result, reasoning multiple choice, timms. }\end{array}$ \\
\hline 6 & $\begin{array}{l}\text { 4d development, bloom, difficulty level of packet, } \\
\text { empirical validity, general criterium, higher order }\end{array}$
\end{tabular}

thinking skill, item discrimination analysis, item distractor, multiple choice test instrument, test package, taxonomy, valid criterium, validity reliabilitty.

721 st century learning, Anchor item, content validation, difficulty level, empirical evidence, expert, high level thinking skill, partial credit model, sets question, thermodynamic material, validation.

8 A Thomas, descriptive method, document analysis, essay problem, G Thorne, high level thinking skill, mann whitney, national exam physics, qualitative approach, simple harmonic motion

9 pengembangan soal high order thinking skill, uas, indikator hots, daya beda soal baik, level menganalisis dan mengevaluasi, reliabilitas, soal hots, soal menurut taksonomi, un, usbn

10 uji validitas, metode deskriptif kuantitatif, penelitian deskriptif, materi kalor, tes berbentuk essay, tes tertulis, profil hot, validator

11 Adams, alpha chonbrach, application, assessment guideline, deception question, discrimination, excellent reliability, expert test, fluid material, rasch model analysis, tier multiple choice, weiman, winstep

12 soal hot, ganda dan uraian, instrumen hots, materi gerak lurus, penelitian deskriptif kuantitatif, model ADDIE terbatas, validitas.

13 d model, daya beda baik, daya beda cukup, higher order thinking skill, materi usaha dan energi, reliabilitas sangat tinggi, tingkat kesukaran sedang, tingkat kesukaran sulit

14 kesukaran item, mardapi, materi optika, rasch model, quest dan parscale, reliabilitas

15 4d development model, fluid, harmonis vibration, instruments validation test

16 penialaian autentik, mencakup high order thinking skill, analisis varian

17 aiken formula, analysing reliability, diagnostict test, modification model, oreondo, rasch model, software winstep.

18 ADDIE approach, heat learning,

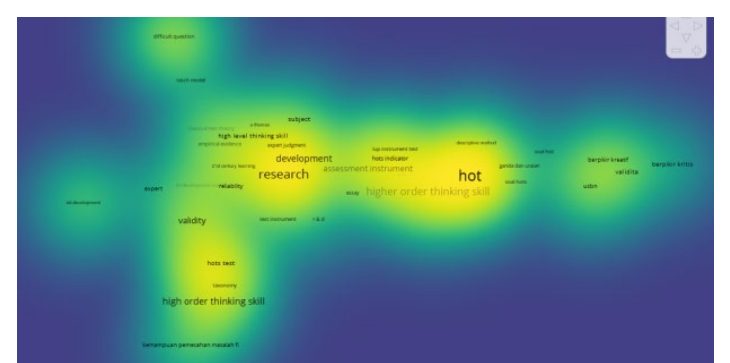

Gambar 4. Tampilan VOSviewer pada density visualization

Berdasarkan keterkaitan tersebut terdapat 2 density visualization yang paling besar yaitu HOT dan research yang menghubungkan keterkaitan kata teserbut dengan kuat seperti yang terlihat pada Gambar 
4. Density visualization yang terbesar kedua yaitu research dan higher order thinking skill.

Apabila kata Research disorot maka, kata tersebut akan memiliki hubungan erat dengan beberapa kata yang menjelaskan bahwa kata research berkaitan dengan penelitian pada pengembangan instrumen penilaian HOT dengan dominasi pada tes pilihan ganda dan uraian yang mengembangkan soal dengan pedoman indikator HOTS dan KKO dengan dominasi metode penelitian $r$ \& $d, 4 D$, dan metode deskriptif seperti yang di lihat pada Gambar 5 (a). Pada Gambar 5 (b) dengan menyorot kata HOT, beberapa kata yang berhubung pada kata research kembali terkait dengan tambahan jangkauan yang lebih luas, dimana kata HOT berhubung pada USBN, berpikir kritis dan kemampuan pemecahan masalah fisika.

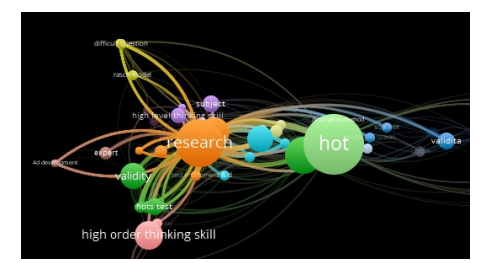

(a)

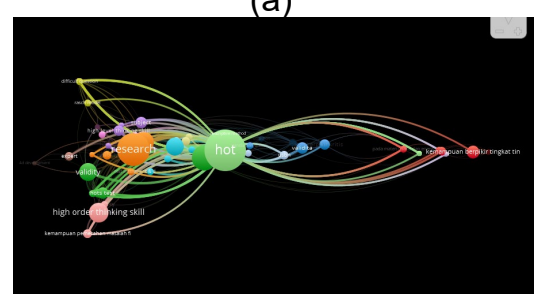

(b)

Gambar 5. Sorotan Pada Kata Kunci. (a) research, (b) HOTS

Pada hasil sorotan kata development berkaitan erat dengan kata pada kata research, hanya saja pada sorotan development tidak berkaitan dengan 4D development, tetapi berkaitan dengan berpikir kreatif dan berpikir kritis yang tidak berkaitan dengan kata research seperti yang terlihat pada Gambar 6 (a). Sedangkan pada hasil sorotan kata higher order thinking skill memiliki kaitan erat dengan kata yang hampir sama juga dengan hot hanya saja cangkupannya lebih kecil. Terdapat beberapa kata yang berkaitan erat dengan kata hot tidak berkaitan dengan kata higher order thinking skill tetapi juga ada kata yang tidak berkaitan dengan hot tetapi berkaitan seperti yang terlihat pada Gambar 6 (b).

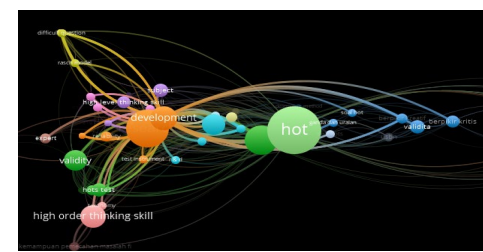

(a)

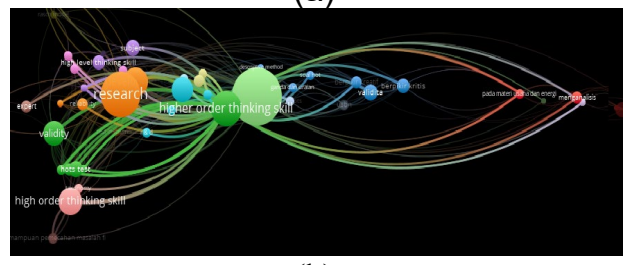

(b)

Gambar 6. Sorotan Pada Kata Kunci. (a) research, (b) HOTS

Hasil pemetaan berdasarkan judul dan abstrak yang ditampilkan VOSviewer pada Gambar 3 apabila dilakukan indentifikasi kembali dengan pengecekan kembali pada artikel maka dapat dideskripsikan berdasarkan tujuan yang mencangkup latar belakang penelitian, jenis penilaian dan bentuk instrumen, indikator pembuatan soal, materi pengembangan, metode penelitian dan proses analisis dari pengembangan instrumen HOTS yang dilakukan sebagai berikut.

\section{Alasan Pengembangan Soal Kemampuan Berpikir Tingkat Tinggi}

Setiap melakukan pengembangan pasti memiliki alasan yang didasari dengan keadaan yang ada. Berdasarkan hasil analisis menunjukkan bahwa Pengembangan instrumen penilaian kemampuan berpikir tingkat tinggi (HOTS) yang dilakukan oleh Agustihana dan Suparno (2019) menunjukkan bahwa pengembangan dilakukan berdasarkan pada tuntutan kemampuan abad 21. Kemendikbud (2019) menyatakan bahwa pemberian soal penilaian berbasis kemampuan berpikir tingkat tinggi (HOTS) dapat meningkatkan kemampuan berpikir kritis, kemampuan berpikir kreatif dan meningkatkan rasa percaya diri.

Menurut Kusuma et al. (2017) pengembangan instrumen pengembangan berpikir tingkat tinggi juga didasarkan pada hasil survey yang dilakukan oleh TIMMS dan PISA. Hal ini sesuai yang disampaikan Kementrian Pendidikan dan Kebudayaan (2019), bahwa diperlukan peningkatan capaian mutu pendidikan Indonesia sehingga dapat meningkatkan rangking Indonesia pada rerata negara-negara OECD. Ada beberapa kemampuan peserta didik Indonesia yang tergolong rendah dan perlu ditingkatkan yaitu pengintegrasian informasi yang diperoleh, tingkat generalisasi berbagai kasus menjadi 
satu solusi yang umum, pengaitan permasalahan di kehidupan nyata dengan konsep mata pelajaran, dan pencarian suatu informasi (Kementrian Pendidikan Dan Kebudayaan, 2019b).

\section{Instrumen Penilaian Kemampuan Berpikir Tingkat Tinggi}

Penilaian berguna untuk mengukur kemampuan peserta didik. Oleh sebab itu dalam setiap pembelajaran selalu dilakukan penilaian. Menurut Permendikbud No. 69 Tahun 2013 terdapat 4 kompetensi yang harus dilakukan penilaian yaitu spiritual, sikap, pengetahuan dan keterampilan. Dalam pengembangan instrumen HOTS capaian yang didapatkan yaitu pada aspek penilaian kemampuan pengetahuannya. Berdasarkan hasil analisis data menunjukkan bahwa jenis penilaian yang dilakukan yang dapat dilakukan yaitu dengan memberikan tes kepada peserta didik.

Instrumen merupakan alat ukur penilaian dalam mengetahui capaian pengetahuan setelah dilakukan pembelajaran (Purwanto, 2006). Berdasarkan Permendikbud No. 69 Tahun 2013, ada beberapa jenis penilaian yang dapat dilakukan seperti penilaian diri, penilaian autentik, ulangan, penilaian berbasis portofolio dan lain sebagainya.

Tabel 2. Jenis Penilaian dan Bentuk Instrumen HOTS Fisika.

\begin{tabular}{|c|c|c|}
\hline $\begin{array}{c}\text { Jenis } \\
\text { Penilaian }\end{array}$ & $\begin{array}{l}\text { Bentuk } \\
\text { Instrum } \\
\text { en }\end{array}$ & Peneliti \\
\hline \multirow[t]{4}{*}{ Tes tertulis } & $\begin{array}{l}\text { Multiple } \\
\text { Choice }\end{array}$ & $\begin{array}{l}\text { (Desilva et al., 2020); (Afriani } \\
\text { et al., 2019); (Marwan et al., } \\
\text { 2020); (Yuliantaningrum \& }\end{array}$ \\
\hline & & $\begin{array}{l}\text { Sunarti, } \\
\text { (Supahar\&Saputro, 2018) }\end{array}$ \\
\hline & $\begin{array}{l}\text { Reasoni } \\
\text { ng } \\
\text { multiple } \\
\text { choice }\end{array}$ & $\begin{array}{l}\text { (Agusta et al., 2019); } \\
\text { (Kistiono, 2019); (Erfianti et } \\
\text { al., 2019); (Kusuma et al., } \\
\text { 2017); (Liana et al., 2018); } \\
\text { (Akhsan et al., 2019) }\end{array}$ \\
\hline & Essay & $\begin{array}{l}\text { (Desilva et al., 2020); } \\
\text { (Hidayah et al., 2018); } \\
\text { (Marwan et al., 2020); } \\
\text { (Ariansyah et al., 2019); } \\
\text { (Rohmah \& Sunarti, 2020); } \\
\text { (Yuliantaningrum \& Sunarti, } \\
\text { 2020); (Daulay \& Sabani, } \\
\text { 2019); (Najihah et al., 2018) }\end{array}$ \\
\hline \multirow[t]{2}{*}{$\begin{array}{l}\text { Package } \\
\text { test }\end{array}$} & $\begin{array}{l}\text { Multiple } \\
\text { Choice }\end{array}$ & (Sari et al., 2018) \\
\hline & - & $\begin{array}{l}\text { (Agustihana \& Suparno, } \\
2019 \text { ) }\end{array}$ \\
\hline $\begin{array}{l}\text { Physics } \\
\text { problem test }\end{array}$ & - & (Siswoyo \& Sunaryo, 2017) \\
\hline
\end{tabular}

\begin{tabular}{lll}
\hline Ujian & - & $\begin{array}{l}\text { (Elyana et al., 2016); (Nisa \& } \\
\text { Wasis, 2018) }\end{array}$ \\
Nasional & - & (Nisa \& Wasis, 2018) \\
\hline UAS & - & (Nisa \& Wasis, 2018) \\
\hline USBN & - & (Widyastuti, 2017) \\
\hline $\begin{array}{l}\text { Penilaian } \\
\text { Autentik }\end{array}$ & & \\
\hline $\begin{array}{l}\text { Diagnostic } \\
\text { test }\end{array}$ & - & (Ramadhan et al., 2019) \\
\hline
\end{tabular}

Berdasarkan review yang dilakukan tidak semua penelitian mengungkapkan fokus jenis penilaian dan bentuk instrumen yang digunakan untuk mengembangkan soal HOTS. Pada Tabel 2 terdapat beberapa penelitian yang menggunakan salah satu penilaian. Bentuk penilaian UN dan USBN merupakan penilaian yang dilakukan oleh negara dalam rangka mengetahui capaian mutu pendidikan di seluruh Indonesia dan UAS merupakan penilaian yang dilakukan oleh institusi setiap akhir semester, maka baik UAS, UN dan USBN diharapkan mampu mengukur tingkat kemampuan berpikir tingkat tinggi (Nisa \& Wasis, 2018). Penilaian autentik adalah penilaian pada jenjang kemampuan peserta didik disertai dengan proses kegiatan peserta didik dalam menyelesaikan permasalahan tersebut sehingga dapat diketahui kemampuan peserta didik sebenarnya (Widyastuti, 2017). Ramadhan et al. (2019) menyatakan bahwa tes diagnostik yang dikembangkan ini dapat membantu guru dalam menjelaskan materi.

Bentuk instrumen tes yang digunakan dalam pengembangan instrumen HOTS, peneliti memilih menggunakan bentuk tes sesuai dengan kebutuhan dan kemudahan tiap bentuk tes dalam mengukur kemampuan berpikir tingkat tinggi. Tes pilihan ganda merupakan salah satu tes yang paling sering digunakan (Sari et al., 2018). Tes pilihan ganda dipilih karena tes ini memiliki beberapa kelebihan seperti dapat mengukur berbagai jenjang pengetahuan, dapat dikoreksi dengan mudah dan bentuk yang tepat untuk melakukan tes dengan peserta yang banyak. Meskipun memiliki berbagai kelebihan, tes pilihan ganda juga memiliki kekurangan (Pendidikan, 2019).

Tes pilihan ganda selama ini menjadi tes yang sering dipakai nyatanya tidak dapat memberikan gambar yang jelas terkait pemahaman dan alur pikir dari peserta didik. Maka dikembangkan tes pilihan ganda beralasan sebagai salah satu solusi untuk menutupi kelemahan tes pilihan ganda tradisional (Sulaeman et al., 2013). Dengan jawaban tingkat dua yang diberikan peserta didik dapat digunakan guru untuk mengetahui tingkat kemampuan berpikir tingkat tinggi dan mengetahui alur pemikiran dari peserta didik (Liana et al., 2018). 
Selain tes pilihan ganda, juga terdapat tes uraian yang paling sering ditemui saat dilakukan penilaian dalam kelas. Soal uraian memiliki tuntutan kepada peserta didik yang mengerjakan untuk menguraikan dan mengorganisasikan pengetahuan yang dimilikinya sehingga peserta didik dapat secara bebas dalam menyelesaikan permasalahan pada soal (Pendidikan, 2019). Hal ini membuat guru dapat mengetahui seberapa tinggi tingkat kemampuan yang dimiliki oleh peserta didik.

\section{Kriteria Soal Kemampuan Berpikir Tingkat Tinggi}

Soal HOTS adalah soal yang tidak hanya mengukur kemampuan mengingat saja dari peserta didik tetapi hingga kemampuan menganalisis dan mencipta. Soal-soal HOTS juga ditujukan agar peserta didik mentransferkan antar konsep, mengintegrasikan informasi, mengaitkan antar satu permasalahan dengan lainnya, menyelesaikan permasalahan tersebut dan memahami infomasi dengan berpikir kritis (Kementrian Pendidikan Dan Kebudayaan, 2019b).

Tabel 3. Kriteria HOTS.

\begin{tabular}{|c|c|}
\hline $\begin{array}{l}\text { Kriteria Soal } \\
\text { HOTS }\end{array}$ & Penulis \\
\hline $\begin{array}{l}\text { Indikator } \\
\text { HOTS }\end{array}$ & $\begin{array}{l}\text { (Desilva et al., 2020); (Erfianti et al., } \\
\text { 2019); (Kusuma et al., 2017); } \\
\text { (Agustihana \& Suparno, 2019); } \\
\text { (Najihah et al., 2018); (Nisa \& } \\
\text { Wasis, 2018) }\end{array}$ \\
\hline KKO & $\begin{array}{l}\text { (Desilva et al., 2020); (Liana et al., } \\
\text { 2018) }\end{array}$ \\
\hline Stimulus & $\begin{array}{l}\text { (Desilva et al., 2020); (Marwan et } \\
\text { al., 2020); (Liana et al., 2018) }\end{array}$ \\
\hline $\begin{array}{l}\text { Taksonomi } \\
\text { Bloom }\end{array}$ & $\begin{array}{l}\text { (Afriani et al., 2019); (Agusta et al., } \\
\text { 2019); (Hidayah et al., 2018); } \\
\text { (Elyana et al., 2016); (Rohmah \& } \\
\text { Sunarti, 2020); (Liana et al., 2018); } \\
\text { (Daulay \& Sabani, 2019); } \\
\text { (Supahar\&Saputro, 2018); (Akhsan } \\
\text { et al., 2019) }\end{array}$ \\
\hline $\begin{array}{l}\text { Permasalahan } \\
\text { Kontekstual }\end{array}$ & (Desilva et al., 2020) \\
\hline $\begin{array}{l}\text { Permasalahan } \\
\text { Fisika }\end{array}$ & (Ariansyah et al., 2019) \\
\hline
\end{tabular}

Taksonomi bloom menjadi salah satu tolak ukur untuk mengembangkan soal HOTS. Karena dalam taksonomi bloom yang disempurnakan oleh Anderson dan Krathwohl telah membagi kemampuan menjadi dua tingkat yaitu LOTS dan HOTS (Akhsan et al., 2019). Pada taksonomi bloom kemampuan berpikir tingkat tinggi terdapat pada level menganalisis, mengevaluasi dan memadukan pengetahuan sehingga kemampuan peserta didik tidak hanya pemahaman konsep tetapi dapat menilai kemampuan pemecahan masalah dan berpikir kritis (Siswoyo \& Sunaryo, 2017).

Indikator soal HOTS yang dapat mengukur kemampuan berpikir tingkat tinggi yaitu soal yang menggunakan kemampuan hingga tahap menganalisis, mengevaluasi dan mencipta (Desilva et al., 2020). Penggunaan KKO dalam pembuatan indikator soal HOTS sendiri sangat menentukan untuk mengetahui tingkat level kognitif yang diukur dalam soal tersebut (Liana et al., 2018). Karena tidak semua penggunaan KKO pada level $\mathrm{C} 1$ hingga C3 bukan termasuk dalam HOTS, karena apabila KKO yang dipakai termasuk C2 tetapi pada soal yang disajikan membutuhkan level kognitif menganalisis terlebih dahulu maka soal tersebut tetap termasuk dalam soal HOTS (Kementrian Pendidikan Dan Kebudayaan, 2019b).

Maka dari susunan pada Tabel 3 dan dibandingkan dalam model penyusunan soal HOTS Fisika, dapat dikatakan bahwa dalam melakukan pengembangan soal kemampuan berpikir tingkat tinggi ada hal-hal yang harus diperhatikan yaitu (1) prinsip-prinsip penilaian yaitu menggunakan stimulus, mengunakan permasalahan baru dan membedakan tingkat kesulitan soal, (2) butir-butir keterampilan yang diukur seperti keterampilan yang tidak hanya mengingat, keterampilan menghubungkan antar konsep, keterampilan mengolah informasi, keterampilan mencari perbedaan antar informasi dan menggunakan informasi, (3) berdasarkan dimensi taksonomi bloom dimana soal hots memakai kategori C4 sampai C6, dan (4) pemilihan kata kerja operasional pada pembuatan indikator soal (Kementrian Pendidikan Dan Kebudayaan, 2019b).

\section{Materi yang telah digunakan dalam Pengembangan Instrumen HOTS}

Soal tes HOTS dikembangkan tidak hanya untuk mengukur tingkat kemampuannya saja, tetapi juga mampu untuk memberikan perjelasan mengenai kemampuan pengetahuan peserta didik terhadap materi yang telah diberikan. Oleh karena itu, penentuan materi dalam pengembangan soal HOTS sangat penting karena dengan terpokoknya materi yang digunakan akan menjadi lebih mudahnya dalam melakukan analisis hasil dari uji coba soal tes yang telah dibuat. Berikut materi yang telah dipakai dalam pengembangan instrumen HOTS. 
Tabel 4. Materi Pengembangan HOTS.

\begin{tabular}{|c|c|}
\hline Materi & Penulis \\
\hline $\begin{array}{l}\text { Elastisitas dan } \\
\text { Hukum Hooke }\end{array}$ & (Desilva et al., 2020) \\
\hline $\begin{array}{lr}\text { Gerak } & \text { Lurus } \\
\text { Berubah } & \text { Beraturan }\end{array}$ & $\begin{array}{l}\text { (Afriani et al., 2019); (Sari et } \\
\text { al., 2018) }\end{array}$ \\
\hline Suhu dan Kalor & $\begin{array}{l}\text { (Agusta et al., 2019); (Rohmah } \\
\text { \& Sunarti, 2020); (Najihah et } \\
\text { al., 2018) }\end{array}$ \\
\hline Getaran Harmonis & $\begin{array}{l}\text { (Hidayah et al., 2018); } \\
\text { (Ariansyah et al., 2019); } \\
\text { (Akhsan et al., 2019) }\end{array}$ \\
\hline Dinamika Partikel & (Kistiono, 2019) \\
\hline Fluida Statis & $\begin{array}{l}\text { (Kusuma et al., 2017); (Liana } \\
\text { et al., 2018); (Akhsan et al., } \\
\text { 2019) }\end{array}$ \\
\hline $\begin{array}{ll}\text { Gerak } & \text { Lurus } \\
\text { Beraturan } & \\
\end{array}$ & (Sari et al., 2018) \\
\hline Fluida Dinamis & $\begin{array}{l}\text { (Siswoyo \& Sunaryo, 2017); } \\
\text { (Liana et al., 2018); (Akhsan et } \\
\text { al., 2019) }\end{array}$ \\
\hline Termodinamika & (Agustihana \& Suparno, 2019) \\
\hline Gerak Lurus & $\begin{array}{l}\text { (Yuliantaningrum \& Sunarti, } \\
\text { 2020) }\end{array}$ \\
\hline Usaha dan Energi & (Daulay \& Sabani, 2019) \\
\hline Optika & (Supahar\&Saputro, 2018) \\
\hline $\begin{array}{ll}\text { Gerak } & \text { Lurus } \\
\text { Berubah } & \text { Tidak } \\
\text { Beraturan } & \end{array}$ & (Ramadhan et al., 2019) \\
\hline
\end{tabular}

Berdasarkan Tabel 4 dapat dilihat bahwa pengembangan instrumen HOTS lebih sering dilakukan pada materi suhu dan kalor, getaran harmonis, fluida statis dan fluida dinamis. Penentuan materi dalam melakukan pengembangan sangat penting dilakukan karena dengan pemilihan materi tersebut dapat digunakan untuk mengukur kemampuan HOT yang lebih terstruktur. Selain itu juga dapat mengetahui tingkat pemahaman peserta didik dalam suatu pokok materi yang diujikan tersebut. Hal ini sesuai yang dinyatakan oleh Trilling dan Fadel (Liana et al., 2018) bahwa dibutuhkan pengintegrasian content knowledge dalam setiap subjek dan tingkatan pendidikan.

\section{Metode dalam Pengembangan Instrumen HOTS}

Langkah-langkah

proses pengembangan instrumen penilaian dilakukan secara terstruktur disebut sebagai metode penelitian. Berdasarkan Tabel 3 terdapat lima pengembangan yang menggunakan metode penelitain research and development yang dikembangkan oleh Brog and Gall. Metode pengembangan dari Brog and Gall memiliki 10 tahapan penelitian yaitu:

"Research and Information Collecting, Planning, develop preliminary of product, preliminary field testing, product revision, main field testing, operational product revision, operational field testing, the final product revision, dissemination and implementation" (Brog \& Gall, 1983).

Tabel 5 merangkum metode pengembangan instrumen yang digunakan peneliti.

Tabel 1. Contoh Format Tabel.

\begin{tabular}{|c|c|}
\hline Metode & Peneliti \\
\hline $\begin{array}{l}\text { R \& D dari Brog and Gall } \\
8 \text { tahapan }\end{array}$ & (Desilva et al., 2020) \\
\hline \multirow{2}{*}{$\begin{array}{l}\mathrm{R} \& \mathrm{D} \text { dari Brog and Gall } \\
7 \text { tahapan }\end{array}$} & (Afriani et al., 2019) \\
\hline & (Kusuma et al., 2017) \\
\hline \multirow{3}{*}{$\begin{array}{l}\mathrm{R} \& \mathrm{D} \text { dari Brog and Gall } \\
6 \text { tahapan }\end{array}$} & (Agusta et al., 2019) \\
\hline & (Marwan et al., 2020) \\
\hline & (Hidayah et al., 2018) \\
\hline 4D Stage & $\begin{array}{l}\text { (Erfianti et al., 2019); } \\
\text { (Kistiono, 2019); (Sari et } \\
\text { al., 2018); (Daulay \& } \\
\text { Sabani, 2019); (Akhsan } \\
\text { et al., 2019) }\end{array}$ \\
\hline $\begin{array}{l}\text { Descriptive qualitative } \\
\text { approach }\end{array}$ & $\begin{array}{l}\text { (Ariansyah et al., 2019); } \\
\text { (Rohmah \& Sunarti, } \\
\text { 2020) }\end{array}$ \\
\hline $\begin{array}{l}\text { Descriptive document } \\
\text { analysis }\end{array}$ & (Elyana et al., 2016) \\
\hline ADDIE & $\begin{array}{l}\text { (Yuliantaningrum \& } \\
\text { Sunarti, 2020); (Najihah } \\
\text { et al., 2018) }\end{array}$ \\
\hline $\begin{array}{l}\text { Pengembangan tes } \\
\text { Adams dan Weiman }\end{array}$ & (Liana et al., 2018) \\
\hline $\begin{array}{l}\text { Pengembangan tes } \\
\text { Mardapi }\end{array}$ & $\begin{array}{l}\text { (Supahar\&Saputro, } \\
\text { 2018) }\end{array}$ \\
\hline $\begin{array}{lr}\text { Pengembangan } & \\
\text { instumen } & \text { dengan } \\
\text { modifikasi } & \text { Model } \\
\text { Oreondo } & \\
\end{array}$ & (Ramadhan et al., 2019) \\
\hline Pengembangan Awal & $\begin{array}{l}\text { (Agustihana \& Suparno, } \\
\text { 2019) }\end{array}$ \\
\hline
\end{tabular}

Berdasarkan Tabel 5 tersebut dapat dilihat bahwa penggunaan metode yang paling sering yaitu metode $R \& D$ dari Brog dan Gall. Namun setiap pengembangan terdapat penyederhaan tahapan sesuai dengan kebutuhan pada penelitian yang dilakukan. Metode pengembangan yang kedua yang terbanyak yaitu Metode 4D Stage. Metode 4D ini merupakan metode penyederhaan dari metode $R$ \& $D$ yang dilakukan oleh Tiaragajan menjadi 4 langkah saja (Sari et al., 2018).

\section{Proses Uji dan Analisis Kelayakan Instrumen HOTS}

Kelayakan instrumen penilaian dapat ditinjau dari beberapa sisi seperti tingkat validitas instrumen, keajegan/reliabilitas instrumen, tingkat kesukaran, daya beda, maupun kemampuan pengecoh jawaban soal. Masing-masing kelayakan itu diperoleh 
melaului proses uji coba instrumen dan hasil uji coba instrumen dapat dianalisis secara statistis. Gambar 5 menunjukkan proses penentuan kelayakan yang digunakan peneliti dalam mengembangkan instrumen HOTS Fisika di SMA.

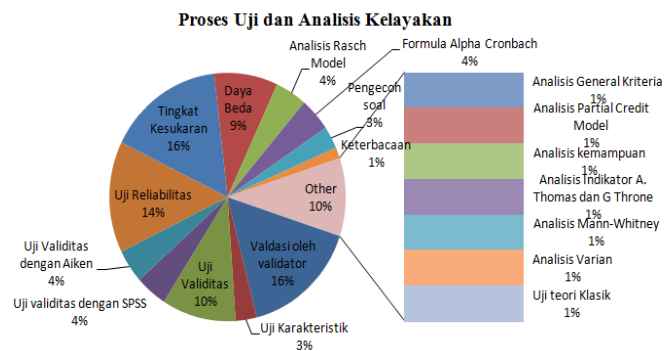

Gambar 6. Proses Uji dan Analisis Kelayakan Instrumen

Berdasarkan Gambar 6 tersebut diketahui bahwa dalam melakukan proses uji dan analisis kelayakan suatu instrumen terdapat beberapa macam jenis. Pada pengembangan instrumen HOTS proses uji dan analisis kelayakan yang paling sering dilakukan yaitu melakukan uji validasi dengan ahli, validitas, reliabilitas, tingkat kesukaran, daya beda dan analisis model Rasch.

\section{SIMPULAN DAN SARAN}

Berdasarkan hasil review yang telah dilakukan didapatkan beberapa kesimpulan terkait hal yang melatarbelakangi penelitian, bentuk instrumen yang digunakan, kriteria dalam pengembangan soal, materi, metode pengembangan, dan metode analisis yang digunakan dalam pengembangan instrumen kemampuan berpikir tingkat tinggi. Pertama, hal yang melatarbelakangi beberapa pengembangan instrumen kemampuan berpikir tingkat tinggi berkaitan dengan tuntutan abad 21 dan hasil survey PISA dan TIMMS tentang capaian mutu pendidikan. Kedua terdapat beberapa bentuk instrumen penilaian kemampuan berpikir tingkat tinggi yang dapat digunakan yaitu multiple choice, reasoning multiple choice, dan essay. Ketiga, dalam melakukan pengembangan soal kemampuan berpikir tingkat tinggi ada beberapa kriteria yang dapat diperhatikan yaitu memperhatikan indikator soal HOTS, menggunakan stimulus, menyajikan permasalahan dalam soal, memperhatikan taksonomi bloom dan menggunakan KKO yang sesuai. Keempat, materi yang digunakan dalam lima tahun terakhir yaitu Elastisitas dan Hukum Hooke, GLBB, Suhu dan Kalor, Getaran Harmonis, Dinamika Partikel, Fluida Statis, GLB, Fluida Dinamis, Termodinamika, Gerak Lurus, Usaha dan Energi, Optika dan Gerak Lurus Berubah Tidak Beraturan. Kelima, metode penelitian dalam pengembangan instrumen penilaian kemampuan berpikir tingkat tinggi juga bermacam-macam sesuai dengan tujuan nya seperti menggunakan metode research and development dari Brog and Gall, metode 4D stage, metode deskriptif kualitatif, deskriptif analisis dokumen, metode ADDIE, metode pengembangan tes Adams dan Weiman, metode pengembangan tes dari Mardapi, metode pengembangan instumen dengan modifikasi Model Oreondo dan metode pengembangan awal. Keenam, terdapat beberapa metode analisis yang dapat digunakan dalam menyajikan hasil penelitian yang telah dilakukan yaitu dengan melakukan uji kevalidan dari validator, uji karakteristik, uji validitas, uji reliabilitas, uji tingkat kesukaran, uji daya beda, analisis model Rasch, analisis dengan formula Alpha Crobanch, uji pengecoh soal, uji keterbacaan, analisis general kriteria, analisis partial credit model, analisis kemampuan, analisis indikator $\mathrm{A}$. Thomas dan G. Throne, analisis Mann-Whitney, analisis varian, dan analisis uji teori klasik.

\section{UCAPAN TERIMAKASIH}

Ucapa terima kasih kami sampaikan kepada seluruh pihak yang telah memberikan kontribusi dalam penyempurnaan artikel ini.

\section{DAFTAR RUJUKAN}

Afriani, E., Tiur Maria, H. S., \& Oktavianty, E. (2019). Pengembangan Tes Higher Order Thinking Skills (Hots) Materi Gerak Lurus Berubah Beraturan Untuk Sma. Jurnal Pendidikan Dan Pembelajaran Khatulistiwa, 8(3), 1-12.

Agusta, S., Sitompul, S. S., \& Arsyid, S. B. (2019). Pengembangan Tes Higher Order Thinking Skill ( Hots ) Pada Materi Suhu Dan Kalor Untuk Sma Artikel Penelitian Oleh: Pengembangan Tes Higher Order Thinking Skill ( Hots ) Pada Materi Suhu Dan Kalor Untuk Sma. Jurnal Pendidikan Dan Pembelajaran, 08(10). https://jurnal.untan.ac.id/index.php/jpdpb/ article/view/36254

Agustihana, S., \& Suparno, S. (2019). Development of HOTS Oriented Cognitive Problems in Thermodynamics for Senior High Schools. Jurnal Penelitian Fisika Dan Aplikasinya (JPFA). https://journal.unesa.ac.id/index.php/jpfa/ article/view/3075

Akhsan, H., Wiyono, K., Novianti, R., Melvany, N. E., \& Ariska, M. (2019). Pengembangan Instrumen Tes Kemampuan Berpikir Tingkat Tinggi Materi Fluida dan Getaran Harmonis. Jurnal Inovasi Pendidikan, 09(02), 33-40. 
http://sij-

inovpend.ejournal.unsri.ac.id/index.php/si j-inovpend/article/view/49

Ariansyah, Sitompul, S. S., \& Arsyid, S. B. (2019). Analisis kemampuan menyelesaikan soal HOTS fisika materi getaran harmonis di SMA Kristen Immanuel Pontianak. Jurnal Pendidikan Dan Pembelajaran Khatulistiwa, 08(06).

Ayumniyya, L., \& Setyarsih, W. (2021). Profil Kemampuan Berpikir Tingkat Tinggi Siswa SMA Dalam Pemecahan Masalah Pada Materi Hukum Newton. IPF : Inovasi Pendidika Fisika, 10(1), 50-58.

Daulay, J., \& Sabani. (2019). Pengembangan Instrumen Bebasis Higher Order Thinking Skills (Hots) Pada Materi Usaha Dan Energi Kelas X Sma Negeri 1 Binjai Kabupaten Langkat T.P 2018/ 2019. digilib.unimed.ac.id.

http://digilib.unimed.ac.id/id/eprint/39549

Desilva, D., Sakti, I., \& Medriati, R. (2020). Pengembangan Instrumen Penilaian Hasil Belajar Fisika Berorientasi Hots (Higher Order Thinking Skills) Pada Materi Elastisitas Dan Hukum Hooke. Jurnal Kumparan Fisika, 03(01), 41-50. https://core.ac.uk/download/pdf/3271054 20.pdf

Elyana, Yennita, \& Fakhruddin, F. (2016). Analysis Higher Order Thinking Skills ( Hots ) Student Man 2 Model Pekanbaru in Problem Solving of Physic National Exam. 1-9.

Erfianti, L., Istiyono, E., \& Kuswanto, H. (2019). Developing Lup Instrument Test to Measure Higher Order Thinking Skills (HOTS) Bloomian for Senior High School Students. International Journal of Educational Research Review, 320-329. https://doi.org/10.24331/ijere.573863

Hidayah, N., Silitonga, H. T. M., \& Mahmuda, D. (2018). Pengembangan Tes Higher Order Thinking Skill (Hots) Pada Materi Getaran Harmonis Untuk SMA. Jurnal Pendidikan Dan Pembelajaran Khatulistiwa, 07(07). https://jurnal.untan.ac.id/index.php/jpdpb/ article/view/26464

Kementrian Pendidikan Dan Kebudayaan. (2019a). Hasil PISA Indonesia 2018: Akses Makin Meluas, Saatnya Tingkatkan Kualitas.

https://www.kemdikbud.go.id/main/blog/2 019/12/hasil-pisa-indonesia-2018-aksesmakin-meluas-saatnya-tingkatkankualitas

Kementrian Pendidikan Dan Kebudayaan. (2019b). Modul Penyusunan Soal Keterampilan Berpikir Tingkat Tinggi (Higher Order Thinking Skills) Fisika.
Kistiono, K. (2019). Pengembangan Tes Kemampuan Berpikir Tingkat Tinggi Fisika SMA. In Jurnal Inovasi dan Pembelajaran Fisika. core.ac.uk. https://core.ac.uk/download/pdf/2678230 73.pdf

Kurniawan, E. S., Mundilarto, M., \& Istiyono, E. (2020). Synectic HOTS oriented: Development of teaching materials for high school physics learning. Universal Journal of Educational Research, 8(11), 5547-5554.

https://doi.org/10.13189/ujer.2020.08115 8

Kusuma, M. D., Rosidin, U., Abdurrahman, A., \& Suyatna, A. (2017). The Development of Higher Order Thinking Skill (Hots) Instrument Assessment In Physics Study. IOSR Journal of Research \& Method in Education (IOSRJRME), 07(01), 26-32. https://doi.org/10.9790/7388-0701052632

Liana, N., Suana, W., Sesunan, F., \& Abdurrahman. (2018). Pengembangan soal tes berpikir tingkat tinggi materi fluida untuk SMA. Journal of Komodo Science Education, 01(01), 66-78. http://repository.lppm.unila.ac.id/id/eprint/ 12227

Marwan, M., Khaeruddin, K., \& Amin, B. D. (2020). Pengembangan Instrumen Asesmen Higher Order Thinking Skills (HOTS) Pada Bidang Studi Fisika. Prosiding Seminar Nasional Fisika PPs UNM, 02, 116-119. https://ojs.unm.ac.id/semnasfisika/article/ view/14365

Najihah, A. R., Serevina, V., \& Delina, M. (2018). The Development of High Order Thinking Skills (HOTS) Assessment Instrument for Temperature and Heat Learning. Jurnal Penelitian \& Pengembangan Pendidikan Fisika, 4(1), 19-26. https://doi.org/10.21009/1.04103

Nisa, S. K., \& Wasis. (2018). Analisis dan Pengembangan Soal High Order Thinking Skills (HOTS) Mata Pelajaran Fisika Tingkat Sekolah Menengah Atas (SMA). Inovasi Pendidikan Fisika. https://jurnalmahasiswa.unesa.ac.id/inde x.php/inovasi-pendidikanfisika/article/view/24140

Pendidikan, P. P. (2019). Panduan Penilaian Tertulis.

Purwanto, N. (2006). Prinsipprinsip dan Teknik Evaluasi Pengajaran. Remaja Rosdakarya.

Ramadhan, S., Mardapi, D., Prasetyo, Z. K., Ramadhan, S., Mardapi, D., Prasetyo, Z. K., \& Utomo, H. B. (2019). The Development of an Instrument to Measure 
the Higher Order Thinking Skill in Physics. European Journal of Educational Research, 08(03), 743-751. https://eric.ed.gov/?id=EJ1222277

Rohmah, U. A., \& Sunarti, T. (2020). Profil Higher Order Thinking Skills (HOTS) Peserta Didik SMA Pada Materi Kalor. 09(03), 466-472.

Sains, K. (2019). Menilik Kualitas Pendidikan Indonesia Menurut PISA 3 Periode Terakhir.

https://kumparan.com/kumparansains/me nilik-kualitas-pendidikan-indonesiamenurut-pisa-3-periode-terakhir1sO0SIXNroC

Sari, D. R. U., Wahyuni, S., \& Bachtiar, R. W. (2018). Pengembangan Instrumen Tes Multiple Choice High Order Thinking Padapembelajaran Fisika Berbasis ELearning Di Sma. In Jurnal Pembelajaran Fisika. jurnal.unej.ac.id. https://jurnal.unej.ac.id/index.php/JPF/arti cle/download/7231/5231

Serevina, V., Sari, Y. P., \& Maynastiti, D. (2019). Developing high order thinking skills (HOTS) assessment instrument for fluid static at senior high school. Journal of Physics: Conference Series, 1185(1). https://doi.org/10.1088/1742-

$6596 / 1185 / 1 / 012034$

Setiadi, H. (2016). Pelaksanaan penilaian pada Kurikulum 2013. Jurnal Penelitian Dan Evaluasi Pendidikan, 20(2), 166-178. https://doi.org/10.21831/pep.v20i2.7173

Sidiq, M. (2019). Panduan Analisis Bibliometrik Sederhana. June. https://doi.org/10.13140/RG.2.2.15688.37 125

Siswoyo, S., \& Sunaryo, S. (2017). High Order Thinking Skills: Analisis Soal dan Implementasinya dalam Pembelajaran Fisika di Sekolah Menengah Atas. Jurnal Penelitian \& Pengembangan Pendidikan Fisika, $\quad$ 03(01). http://journal.unj.ac.id/unj/index.php/jpppf/ article/view/2498

Sulaeman, N. F., Komariyah, L., \& Yani, S. F. (2013). Analysis of High School Students ' Misconception in. 210-216.

Supahar\&Saputro, B. (2018). Pengembangan Instrumen Penilaian Kemampuan Berpikir Tingkat Tinggi Untuk Mengukur Pencapaian Hasil Belajar Fisika Peserta Didik SMA Kelas XI Materi Optika. EJournal Pendidikan Fisika, 7, 1-6.

Widyastuti, E. (2017). Effect Of Authentical Assessment And High Order Thinking Skill (Hots) Against Troubleshooting Physical Problems (An Experiment in The Students of SMA Negeri 2 Depok City). Jurnal

Evaluasi Pendidikan, 08(02), 109-116. http://journal.unj.ac.id/unj/index.php/jep/a rticle/view/7114

Yuliantaningrum, L., \& Sunarti, T. (2020). Pengembangan Instrumen Soal Hots Untuk Mengukur Keterampilan Berpikir Kritis, Berpikir Kreatif, Dan Pemecahan Masalah Materi Gerak Lurus Pada Peserta Didik SMA. Inovasi Pendidikan Fisika (IPF), 09(02), 76-82. https://jurnalmahasiswa.unesa.ac.id/inde x.php/inovasi-pendidikanfisika/article/view/33368 